AJIE - Asian Journal of Innovation and Entrepreneurship

(e-ISSN: 2477-0574 ; p-ISSN: 2477-3824)

Vol. 01, No. 02, May 2016

\title{
MODEL PEMBERDAYAAN KARANG TARUNA DI KECAMATAN CERME KABUPATEN GRESIK
}

\author{
Suprayoga, Andi Iswoyo, Ramon Syahrial \\ Universitas Wijaya Putra \\ email : suprayoga@uwp.ac.id
}

\begin{abstract}
As one of the nation's potential is calculated, then naturally Youth were able to show his identity as an organization that can bring changes to the welfare of its citizens and the surrounding communities. One of the problems encountered in the context of national development is the problem of youth competency is low and likely to be unemployed in the village. Real conditions show that many young people do not have jobs and are not capable of creating jobs.

Method development and empowerment of the young generation in the container Youth organizations in Cerme Lor village and sub-district village Cagakagung Cerme done in the form of counseling, training and mentoring. Counseling and training that is done, of course, oriented towards the fulfillment of the dimensions of cognitive, affective and psychomotor. Meteri counseling and training among them is The Role of youth in the face of the MEA, High Positive and Utilization, Entrepreneurship and Success Story, dna Organizational Leadership, Business training including; welding (canopies, fences, etc.), repair of the air conditioning (AC and fridge), Oyster Mushroom Cultivation and Processing, as well as assistance with job training and the development of joint business group.

Results achieved, among others, at the stage of pre-implementation are the activities undertaken prior to the main activity in IbM This includes activities for the coordination and silaturrahmi with Village Head Cerme Lor village head Cagakagung, and administrators both Karang Taruna of two villages to reorder plan activities tailored to the allocation of available funds. During the implementation phase covers the main activities, carried out in the form of education (lectures and question-answer) and training to improve the skills and competence and in evaluating and monitoring are the activities undertaken to monitor the impact of education and training provided and also for monitoring trainees dimagangkan. The impact of the implementation of the Youth Empowerment IbM among others; Both Partners has formed a Business Group Machine Tools and canopy located in the village of Cerme Lor district. Gresik; Trainees AC partly been recruited by Entrepreneur plumber and Air Conditioning; Some members of the Youth daughter had started a business making and selling a variety of processed foods Oyster Mushrooms; Organizational activity in both increasing Partners marked with several activities by the Village Head implementation submitted to the Youth (Payment of Electricity, Water, PHBN, etc.)
\end{abstract}

Keywords: Youth, Empowerment, Youth Productive

\begin{abstract}
ABSTRAK
Sebagai salah satu potensi bangsa yang sangat diperhitungkan, maka sewajarnya Karang Taruna mampu menunjukkan jatidirinya sebagai organisasi yang mampu membawa perubahan bagi peningkatan kesejahteraan warganya dan masyarakat sekitarnya. Salah satu permasalahan yang dihadapi dalam konteks pembangunan nasional yaitu masalah kompetensi pemuda yang rendah dan cenderung menjadi pengangguran di desa. Kondisi riil menunjukkan bahwa banyak pemuda yang tidak memiliki pekerjaan serta tidak mampu menciptakan lapangan pekerjaan.
\end{abstract}


Metode pengembangan dan pemberdayaan generasi muda dalam wadah organisasi Karang Taruna di Desa Cerme Lor dan Desa Cagakagung Kecamatan Cerme dilakukan dalam bentuk penyuluhan, pelatihan dan pendampingan. Penyuluhan dan pelatihan yang dilakukan, tentunya, diorientasikan pada pemenuhan dimensi kognitif, afektif dan psikomotor. Meteri penyuluhan dan pelatihan di antaranya adalah Peran generasi muda dalam menghadapi MEA, Internet Positif dan Pemanfaatannya, Kewirausahaan dan Success Story, Kepemimpinan dna Keorganisasian, Pelatihan usaha diantaranya; pengelasan (kanopi, pagar, dll), reparasi pendingin udara (AC dan kulkas), Budidaya dan Pengolahan Jamur Tiram, serta pendampingan melalui magang kerja dan pengembangan kelompok usaha bersama.

Hasil yang dicapai antara lain pada tahap pra pelaksanaan adalah kegiatan-kegiatan yang dilaksanakan sebelum kegiatan utama dalam IbM ini, meliputi kegiatan koordinasi dan silaturrahmi dengan Kepala Desa Cerme Lor, Kepala Desa Cagakagung, dan pengurus kedua Karang Taruna dari 2 desa tersebut untuk menyusun ulang rencana kegiatan disesuaikan dengan alokasi dana yang tersedia. Pada tahap pelaksanaan meliputi kegiatan-kegiatan utama, yang dilakukan dalam bentuk penyuluhan (ceramah dan tanya jawab) dan pelatihan untuk meningkatkan ketrampilan dan kompetensi dan pada tahap evaluasi dan monitoring adalah kegiatan-kegiatan yang dilakukan untuk memonitoring dampak dari penyuluhan dan pelatihan yang telah diberikan dan juga untuk memonitoring peserta pelatihan yang dimagangkan. Dampak dari pelaksanaan IbM Pemberdayaan Karang Taruna ini antara lain; Kedua Mitra sudah membentuk Kelompok Usaha Mesin Perkakas dan Kanopi yang bertempat di Desa Cerme Lor Kab. Gresik; Peserta pelatihan AC sebagian sudah direkrut oleh Pengusaha reparasi AC dan Pendingin Udara; Beberapa anggota Karang Taruna putri sudah memulai usaha membuat dan menjual aneka makanan olahan Jamur Tiram; Aktivitas keorganisasian di kedua Mitra semakin meningkat ditandai dengan beberapa kegiatan yang oleh Kepala Desa pelaksanaannya diserahkan kepada Karang Taruna (Pembayaran Listrik, Air, PHBN, dll)

Kata Kunci: Karang Taruna, Pemberdayaan, Pemuda Produktif

\section{PENDAHULUAN}

Karang Taruna merupakan salah satu pilar bangsa yang memiliki potensi untuk terus dikembangkan dalam rangka turut serta membangun bangsa dan negara. Sebagai salah satu potensi bangsa yang sangat diperhitungkan, maka sewajarnya Karang Taruna mampu menunjukkan jatidirinya sebagai organisasi yang mampu membawa perubahan bagi peningkatan kesejahteraan warganya dan masyarakat sekitarnya.

Sebagai wadah pengembangan potensi generasi muda Karang Taruna diatur dalam Peraturan Menteri Sosial RI No. 77/HUK/2010 tentang Pedoman Dasar Karang Taruna yang menyatakan bahwa Karang Taruna adalah organisasi sosial kemasyarakatan sebagai wadah dan sarana pengembangan setiap anggota masyarakat yang tumbuh dan berkembang atas dasar kesadaran dan tanggung jawab sosial dari, oleh dan untuk masyarakat terutama generasi muda di wilayah desa/kelurahan terutama bergerak dibidang usaha kesejahteraan sosial.

Sasaran yang ingin dicapai oleh Karang Taruna dititikberatkan pada kesadaran dan tanggung jawab sosial dalam pelaksanaan pembangunan, sehingga dapat mewujudkan dengan baik kesejahteraan sosial yang dapat dinikmati oleh seluruh masyarakat. Untuk mencapai sasaran tersebut, maka tugas pokok Karang Taruna adalah bersama-sama dengan pemerintah dan komponen masyarakat lainnya menanggulangi berbagai masalah pembangunan sehingga potensi karang taruna dapat dirasakan oleh masyarakat di lingkungannya.

Salah satu permasalahan yang dihadapi dalam konteks pembangunan nasional yaitu masalah kompetensi pemuda yang rendah dan cenderung menjadi pengangguran di desa. Kondisi riil menunjukkan bahwa banyak pemuda yang tidak memiliki pekerjaan serta 
tidak mampu menciptakan lapangan pekerjaan.

Sebagian besar diantara mereka menjadi pemuda penggangguran sehingga potensi yang dimilikinya tidak dapat berkembang sesuai dengan yang diharapkan. Mereka menjadi pemuda yang tidak produktif serta tidak mampu menunjukkan jati dirinya sebagai generasi penerus harapan bangsa. Masalah pemuda yang tidak produktif ini menjadi salah satu masalah yang sangat pelik untuk dipecahkan.

Terkait kondisi tersebut maka Karang Taruna sebagai salah satu organisasi penggerak pembangunan pemuda di Desa perlu menunjukkan perannya untuk membantu dalam mengatasi berbagai masalah yang dihadapi pemuda terutama yang berkaitan dengan upaya untuk menciptakan pemuda produktif.

Peran yang dapat dilakukan Karang Taruna dalam membantu menciptakan pemuda produktif antara lain dengan memfasilitasi kegiatan pelatihan untuk meningkatkan keterampilan pemuda dalam menguasai keahlian dalam bidang tertentu. Karang taruna juga dapat memfasilitasi pembukaan lapangan pekerjaan baru dengan menjalin kerjasama dengan perusahaan atau instansi yang berwenang.

Untuk mengaktualisasikannya Karang Taruna perlu memperbaiki dan meningkatkan kinerja organisasinya sehingga mampu membantu menciptakan pemuda produktif. Semua anggota karang taruna wajib bahu membahu untuk merancang program yang sifatnya membantu pemuda dalam meningkatkan kualitas hidupnya. Dengan cara ini maka potensi karang taruna dapat dirasakan manfaatnya oleh pemuda sehingga penciptaan pemuda produktif dapat dilakukan dengan baik.

Pemuda produktif memiliki beberapa ciri yang merupakan manifestasi dari standarisasi dari pemuda produktif sebagaimana yang dikemukakan Yamani dalam Puluhulawa (2012) sebagai berikut; 1) inovatif dan kreatif, 2) memiliki semangat untuk berusaha, dan 3) komitmen terhadap pekerjaan. Ketiga ciri ini menjadi bagian yang perlu dimiliki oleh pemuda desa dalam melakukan berbagai aktivitas sehingga masuk dalam kategori produktif. Bagi para pemuda putus sekolah dan pemuda pengangguran perlu difasilitasi oleh karang taruna untuk memiliki berbagai keterampilan sesuai dengan yang telah diprogramkan. Pemuda putus sekolah dan pemuda pengangguran dapat memilih keterampilan tertentu untuk dikembangkan dan selanjutnya mereka dilatih dan dikembangkan komitmennya untuk memiliki jiwa inovatif dan kreatif, semangat untuk berusaha, dan komitmen terhadap pekerjaan yang dilakukan Hasil pengamatan yang dilakukan di Desa Cagakagung dan Desa Cerme Lor di Kecamatan Cerme Kabupaten Gresik menunjukkan bahwa Karang Taruna belum optimal dalam melaksanakan perannya untuk menciptakan pemuda produktif. Dalam konteks ini upaya untuk menciptakan pemuda produktif belum menjadi program utama Karang Taruna yang ada di Desa Cagakagung dan Desa Cerme Lor Kecamatan Cerme Kabupaten Gresik. Karang Taruna lebih fokus pada urusan politik di desa. Mereka lebih banyak memfasilitasi kegiatan pengembangan demokrasi dan cenderung mengabaikan upaya untuk memberdayakan potensi pemuda melalui penciptaan pemuda produktif. Hal ini yang menjadikan karang taruna sebagai salah satu organisasi kemasyarakatan kurang memberi peran dalam membantu menciptakan pemuda produktif.

Kondisi yang sempat diamati di lapangan menunjukkan bahwa karang taruna belum bisa melaksanakan fungsinya untuk meningkatkan kesejahteraan pemuda anggotanya. Hal ini terjadi khususnya pada pemuda pengangguran dan pemuda putus sekolah. Data dari Dinas Tenaga Kerja Kabupaten Gresik Tahun 2012 menunjukkan bahwajumlah pencari kerja masih cukup tinggi, dimana ada 3.301 pencari kerja, jumlah ini meningkat dibandingkan tahun sebelumnya yaitu sebesar 2.904 pencari kerja. 
Tabel 1 Jumlah Pencari Kerja Menurut Jenis Kelamin dan Tingkat Pendidikan di Kabupaten Gresik Tahun 2012

\begin{tabular}{clcccc}
\hline \multirow{2}{*}{ No } & & Uraian & Laki-laki & Perempuan & Jumlah \\
\hline 1 & Belum Tamat SD & - & - & - \\
\hline 2 & Tamat SD & 16 & - & 16 \\
\hline 3 & Tamat SLTP & 40 & 13 & 53 \\
\hline \multirow{2}{*}{4} & Tamat SLTA & - & - & - \\
\cline { 2 - 5 } & a. Umum & 657 & 460 & 1.117 \\
\cline { 2 - 5 } & b. Kejuruan & 559 & 63 & 622 \\
\hline \multirow{2}{*}{5} & Tamat Akademi & & & \\
\cline { 2 - 5 } & a. Diploma I dan II & 10 & 17 & 27 \\
\cline { 2 - 5 } & b. Diploma III & 105 & 325 & - \\
\hline 6 & Sarjana & - & - & $\mathbf{3 . 3 0 1}$ \\
\hline & Jumlah & $\mathbf{1 . 8 2 1}$ & $\mathbf{1 . 4 8 0}$ & \\
\hline
\end{tabular}

Sumber : Gresik Dalam Angka Tahun 2013

Dari data statistik Kecamatan Cerme didapat data bahwa sebaian besar penduduk kecamatan Cerme bekerja di dunia Industri (34\%) dan $19 \%$ bekerja di sektor Pertanian dan lainnya bekerja di sector konstruksi, perdagangan, angkutan dan lain-lain.
Data di Kecamatan Cerme tahun 2012 menunjukkan bahwa jumlah pemuda pengangguran dan putus sekolah anggota Karang Taruna yang ada di Desa Cagakagung dan Desa Cerme Lor Kecamatan Cerme Kabupaten Gresik cukup tinggi. Data tentang pemuda pengangguran dan putus sekolah tersebut ditampilkan pada tabel di bawah ini

Tabel 2 Data Jumlah Pemuda Pengangguran dan Putus Sekolah Anggota Karang Taruna Desa Cagakagung dan Desa Cerme Lor

\begin{tabular}{cccccc}
\hline \multirow{2}{*}{ No } & Tahun & \multicolumn{2}{c}{ Desa Cagakagung } & \multicolumn{2}{c}{ Desa Cerme Lor } \\
\cline { 3 - 6 } & & $\begin{array}{c}\text { Penganggura } \\
\mathrm{n}\end{array}$ & Putus Sekolah & $\begin{array}{c}\text { Penganggura } \\
\mathrm{n}\end{array}$ & $\begin{array}{c}\text { Putus } \\
\text { Sekolah }\end{array}$ \\
\hline 1 & 2010 & 9 & 5 & 14 & 7 \\
\hline 2 & 2012 & 11 & 4 & 17 & 11 \\
\hline 3 & 2013 & 15 & 4 & 19 & 5 \\
\hline
\end{tabular}

Sumber : Desa Cagakagung dan Desa Cerme Lor

Tabel di atas menunjukkan bahwa Data Pemuda Pengangguran dan Pemuda Putus Sekolah di Desa Cerme Lor dan Desa Cagakagung Kecamatan Cerme dalam 3 tahun terakhir mengalami peningkatan. Hal ini menunjukkan bahwa karang taruna sangat dituntut untuk menunjukkan perannya dalam memberikan keterampilan kepada pemuda pengangguran tersebut agar mampu berkiprah dalam mengembangkan kemampuannya sehingga memiliki keterampilan yang memadai dan dapat bersaing dalam memasuki dunia pekerjaan.

\section{Permasalahan Mitra}

Berdasarkan kondisi obyektif sebagaimana terurai dalam analisis situasi di atas, maka permasalahan mendasar yang dihadapi oleh Karang Taruna di Desa Cerme Lor dan Desa Cagakagung Kecamatan Cerme cenderung identik dan dapat dikualifikasikan dalam 3 (tiga) dimensi, yaitu dimensi kognitif, affektif dan psikomotor sebagai berikut : 
Tabel 3 Permasalahan Mitra I dan Mitra II

\begin{tabular}{|c|c|}
\hline No & Permasalahan \\
\hline 1 & $\begin{array}{l}\text { Dimensi Kognitif } \\
\text { 1. Kurangnya kemauan untuk belajar dan berlatih tentang hal-hal baru yang } \\
\text { mendukung mereka untuk berwirausaha } \\
\text { 2. Kurangnya kesadaran tentang arti penting keberadaan mereka sebagai } \\
\text { generasi muda di tengah-tengah perubahan yang tengah berlangsung } \\
\text { 3. Kurangnya pemahaman tentang arti penting organisasi Karang Taruna sebagai } \\
\text { wadah pengembangan generasi muda nonpartisan dalam peningkatan } \\
\text { kesejahteraan sosial } \\
\text { 4. Kurangnya pengetahuan tentang kepemimpinan dan manajemen } \\
\text { keorganisasian }\end{array}$ \\
\hline 2 & $\begin{array}{l}\text { Dimensi Afektif } \\
\text { 1. Kurangnya kepedulian dan kepekaan terhadap persoalan-persoalan } \\
\text { kemasyarakatan yang berkembang } \\
\text { 2. Kurangnya keberanian untuk melakukan hal-hal dan usaha baru } \\
\text { 3. Kurangnya keberanian untuk memikul tanggung-jawab yang lebih besar }\end{array}$ \\
\hline 3 & $\begin{array}{l}\text { Dimensi Psikomotor } \\
\text { 1. Kurangnya kemampuan dan ketrampilan berwirausaha dan kemandirian tanpa } \\
\text { menggantungkan diri pada orang lain karena rendahnya tingkat pendidikan. } \\
\text { 2. Kurangnya kemampuan dan ketrampilan untuk menggerakan dirinya dan } \\
\text { orang lain pada suatu tujuan tertentu } \\
\text { 3. Kurangnya kemampuan dan ketrampilan untuk mengelola suatu organisasi }\end{array}$ \\
\hline
\end{tabular}

\section{TARGET LUARAN}

Luaran yang ditargetkan melalui kegiatan ini adalah sebuah model pemberdayaan bagi para generasi muda dalam wadah organisasi sosial kepemudaan Karang Taruna agar mereka lebih produktif, berdaya guna bagi dirinya dan lingkungan, terampil, responsif dan kolaboratif.

\section{METODE PELAKSANAAN \\ Tujuan Pemecahan Masalah}

Tujuan kegiatan ini adalah untuk membantu pengembangan dan pemberdayaan generasi muda di Desa Cagakagung dan Desa Cerme Lor Kecamatan Cerme dalam wadah organisasi Karang Taruna untuk mengurangi pengangguran dan pemuda kurang produktif sehingga keberadaannya benar-benar memberikan manfaat yang optimal bagi dirinya, keluarganya dan masyarakat di sekitarnya di tengah-tengah perubahan besar yang berlangsung. Generasi muda dalam wadah organisasi Karang Taruna diharapkan tidak hanya menjadi pelengkap dan/atau obyek dalam gerak dinamika pembangunan yang ada, tetapi menjadi subyek yang terlibat secara langsung dalam perencanaan dan pelaksanaan pembangunan dengan menjadi pemuda yang produktif.

\section{Metode yang ditawarkan}

Metode pengembangan dan pemberdayaan generasi muda dalam wadah organisasi Karang Taruna di Desa Cerme Lor dan Desa Cagakagung Kecamatan Cerme dilakukan dalam bentuk penyuluhan, pelatihan dan pendampingan. Penyuluhan dan pelatihan yang dilakukan, tentunya, diorientasikan pada pemenuhan dimensi kognitif, afektif dan psikomotor. Dengan demikian diharapkan melalui pelatihan-pelatihan yang dilaksanakan, generasi muda yang tergabung dalam wadah organisasi Karang Taruna memiliki kemampuan dan keterampilan untuk berwirausaha mandiri dan mampu bekerja untuk menjadikan dirinya lebih berdaya guna, memiliki ketrampilan menggerakkan dan mengelola usaha bersama, memiliki kesadaran yang tinggi akan eksistensi dirinya di tengahtengah masyarakat dan perubahan, empati terhadap sesama dan lingkungan, keberanian berkreasi dan berinovasi.

Meteri penyuluhan dan pelatihan di antaranya adalah Membangun Keluarga 
Sejahtera, Kewirausahaan, Success Story, Problem Solving \& Motivasi, Pelatihan usaha diantaranya; pengelasan (kanopi, pagar, dll), servis motor ringan, reparasi pendingin udara (AC dan kulkas), pembuatan Alat Peraga Edukasi (APE), pelatihan pemasaran dan pengelolaan keuangan sederhana serta outbound dalam rangka untuk melatih semangat berwirausaha, kepemimpinan dan kerjasama tim.

Sebagaimana pemberdayaan yang sedang dijalankan saat ini, teknik penyampaian materi dalam rangka pemberdayaan Karang Taruna ini dilakukan dengan model ceramah, tanya-jawab dan praktek pelatihan usaha sebagaimana terurai dalam tabel di bawah ini :

Tabel 4 Metode Pemberdayaan Karang Taruna di Desa Cagakagung dan Desa Cerme Lor Kecamatan Cerme

\begin{tabular}{|c|c|c|c|}
\hline No & Permasalahan & Metode & Materi \\
\hline 1 & $\begin{array}{l}\text { Dimensi Kognitif } \\
\text { 1. Kurangnya kemauan untuk belajar dan berlatih } \\
\text { tentang hal-hal baru yang mendukung mereka } \\
\text { untuk berwirausaha } \\
\text { 2. Kurangnya kesadaran tentang arti penting } \\
\text { keberadaan mereka sebagai generasi muda di } \\
\text { tengah-tengah perubahan yang tengah berlangsung } \\
\text { 3. Kurangnya pemahaman tentang arti penting } \\
\text { organisasi Karang Taruna sebagai wadah } \\
\text { pengembangan generasi muda nonpartisan dalam } \\
\text { peningkatan kesejahteraan sosial } \\
\text { 4. Kurangnya pengetahuan tentang kepemimpinan } \\
\text { dan manajemen keorganisasian }\end{array}$ & $\begin{array}{l}\text { Pelatihan } \\
\text { Pelatihan }\end{array}$ & $\begin{array}{l}\text { Pelatihan : } \\
\text { Pengelasan, Reparasi } \\
\text { AC, Budidaya dan } \\
\text { Pengolahan Jamur } \\
\text { Tiram, Internet Positif } \\
\text { dan Pemanfaatannya. } \\
\text { Penyuluhan : } \\
\text { Peran Generasi Muda } \\
\text { dalam menghadapi } \\
\text { MEA, Kewirausahaan } \\
\text { dan Success Story, } \\
\text { Kepemimpinan dan }\end{array}$ \\
\hline 2 & $\begin{array}{l}\text { Dimensi Afektif } \\
\text { 5. Kurangnya kepedulian dan kepekaan terhadap } \\
\text { persoalan-persoalan kemasyarakatan yang } \\
\text { berkembang } \\
\text { 6. Kurangnya keberanian untuk melakukan hal-hal } \\
\text { dan usaha baru } \\
\text { 7. Kurangnya keberanian untuk memikul tanggung- } \\
\text { jawab yang lebih besar }\end{array}$ & $\begin{array}{l}\text { Penyuluhan } \\
\text { Pelatihan dan } \\
\text { Pendampingan } \\
\text { Pelatihan dan } \\
\text { Pendampingan }\end{array}$ & $\begin{array}{l}\text { keorganisasian } \\
\text { Pendampingan: } \\
\text { Praktek Pengelasan } \\
\text { Praktek Reparasi AC } \\
\text { Praktek Wirausaha }\end{array}$ \\
\hline 3 & $\begin{array}{l}\text { Dimensi Psikomotor } \\
\text { 8. Kurangnya kemampuan dan ketrampilan } \\
\text { berwirausaha dan kemandirian tanpa } \\
\text { menggantungkan diri pada orang lain karena } \\
\text { rendahnya tingkat pendidikan. } \\
\text { 9. Kurangnya kemampuan dan ketrampilan untuk } \\
\text { menggerakan dirinya dan orang lain pada suatu } \\
\text { tujuan tertentu } \\
\text { 10. Kurangnya kemampuan dan ketrampilan untuk } \\
\text { mengelola suatu organisasi }\end{array}$ & $\begin{array}{l}\text { Pelatihan dan } \\
\text { Pendampingan } \\
\text { Pelatihan dan } \\
\text { Pendampingan } \\
\text { Pelatihanan } \\
\text { dan } \\
\text { Pendampingan }\end{array}$ & \\
\hline
\end{tabular}


Adapun langkah-langkah penyelesaian masalah dalam rangka pemberdayaan generasi muda dapat digambarkan sebagai berikut :

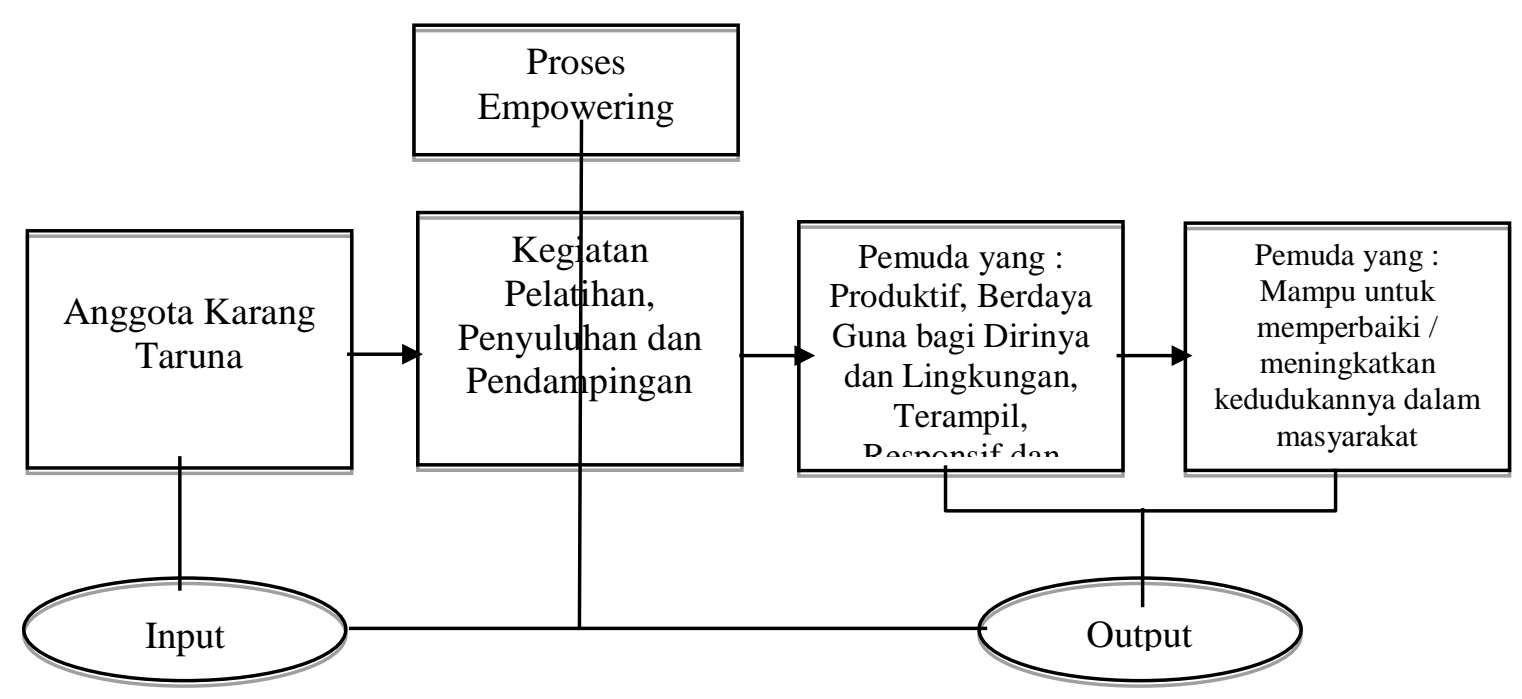

Gambar 1 Langkah-Langkah Penyelesaian Masalah dalam

IbM Pemberdayaan Karang Taruna

\section{HASIL YANG DICAPAI}

Kegiatan pemberdayaan Karang Taruna dilakukan dengan harapan menjadikan generasi muda yang produktif, terampil, responsive dan berdaya guna bagi diri dan lingkungannya, yang terbagi dalam tiga tahapan yaitu tahap pra pelaksanaan, tahap pelaksanaan dan tahap evaluasi dan monitoring.

Tahap pra pelaksanaan adalah kegiatan-kegiatan yang dilaksanakan sebelum kegiatan utama dalam $\mathrm{IbM}$ ini, meliputi kegiatan koordinasi dan silaturrahmi dengan Kepala Desa Cerme Lor, Kepala Desa Cagakagung, dan pengurus kedua Karang Taruna dari 2 desa tersebut untuk menyusun ulang rencana kegiatan disesuaikan dengan alokasi dana yang tersedia.

Tahap pelaksanaan meliputi kegiatankegiatan utama, yang dilakukan dalam bentuk penyuluhan (ceramah dan tanya jawab) dan pelatihan untuk meningkatkan ketrampilan dan kompetensi.

Tahap evaluasi dan monitoring adalah kegiatan-kegiatan yang dilakukan untuk memonitoring dampak dari penyuluhan dan pelatihan yang telah diberikan dan juga untuk memonitoring peserta pelatihan yang dimagangkan

\section{Pra Pelaksanaan.}

Sebelum melakukan kegiatan utama tim IbM Pemberdayaan Karang Taruna desa Cerme Lor dan desa Cagakagung, kecamatan Cerme Kabupaten Gresik, terlebih dahulu mengadakan rapat koordinasi internal pada tanggal 13 April 2015 yang dipimpin ketua tim Suprayoga, SE., M.Si., dan anggota tim Andi Iswoyo, SE., MM. serta Ramon Syahrial, SP., MM. Dalam kegiatan ini membahas tentang kegiatan-kegiatan utama yang akan dilakukan perlu untuk didiskusikan ulang dengan mitra mengingat jumlah alokasi dana yang direncanakan dengan realita ada perubahan yang cukup signifikan. Selain itu juga membahas persiapan yang bersifat administrasi kesektretariatan misalkan surat audensi dengan kepala desa, biodata peserta pemberdayaan, surat kepada nara sumber dan sebagainya.

Kegiatan berikutnya pada tanggal 19 April 2015 tim mengadakan rapat koordinasi dengan pengurus Karang Taruna baik dari Desa Cerme Lor maupun Karang Taruna dari Desa Cagakagung. Pada kesempatan ini tim yang dipimpin oleh Andi Iswoyo, SE., MM. mendiskusikan dengan kedua pengurus tersebut tentang rencana kegiatan yang telah dibuat bersama pada proposal, belum bisa seluruhnya dilaksanakan mengingat jumlah alokasi dana yang diterima sebesar Rp. 
35.500.000,00 (tiga puluh lima juta lima ratus ribu rupiah) dari alokasi awal sebesar Rp. 49.910.000,00 (empat puluh Sembilan juta sembilan ratus sepuluh ribu juta rupiah). Berdasarkan kenyataan itu kedua pengurus Karang Taruna mengusulkan untuk mengambil prioritas yaitu ketrampilan Las listrik dan service AC yang diutamakan, mengingat kegiatan tersebut sangat mungkin diaplikasikan sehingga bisa menjadi alat perekat anggota Karang Taruna karena bagian dari usaha baru bagi Karang Taruna selain pembayaran listrik dan pengohan air minum. Selain itu juga pengurus Karang Taruna menyampaikan juga agar ada kegiatan yang bisa dinikmati anggota Karang Taruna putri, mengingat direncana awal ketrampilan yang diberikan lebih cocok untuk anggota putra, supaya anggota Karang Taruna yang berdaya bukan hanya yang putra tetapi juga yang putri. Pada kesempatan itu tim yang dikoordinir bapak Andi Iswoyo, SE., MM., menawarkan tentang penyuluhan budidaya jamur tiram dan pelatihan aneka olahan jamur tiram untuk makanan seperti : Kebab Jamur, Bakso Jamur, Empal Jamur, Jamur Krispi, Jamur Penyet dan lain sebagainya. Kegiatan tersebut sangat memungkinkan dilakukan oleh anggota Karang Taruna putri. Mendapat masukan tersebut pengurus Karang Taruna putri langsung mengiyakan masukan dari tim. Akhirnya disepakati materi pelatihan berupa Las Listrik, Service AC, Pengolahan aneka masakan Jamur Tiram, sedangkan untuk penyuluhan Karang Taruna mengusulkan dimasukkannya pengetahuan tentang internet, agar para pemuda bisa banyak melihat sisi positifnya internet daripada sisi negatifnya.

Kegiatan selanjutnya mengadakan koordinasi eksternal yang dalam kegiatan ini dengan Kepala Desa Cerme Lor, Kecamatan Cerme, Kabupaten Gresik. Bapak Arifin, ST., dilaksanakan pada tanggal 23 Mei 2015 di Kantor Kepala Desa tersebut. Pada kesempatan ini Tim menyampaikan program yang akan dilakukan kepada Karang Taruna sekaligus untuk meminta masukan dan arahan serta do'a restu agak upaya pemberdayaan Karang Taruna tersebut dapat berhasil sesuai dengan tujuan. Pada kesempatan ini Bapak Kepala Desa sangat mengapresiasi terhadap rencana pemberdayaan Karang Taruna di desanya oleh tim dari Universitas Wijaya Putra. Beliau berharap melalui kegiatan ini keberadaan Karang Taruna yang ada di desanya semakin bergairah dan bersemangat, mengingat yang terjadi saat ini sering kurang stabil. Pada saat-saat tertentu khususnya menjelang kegiatan peringatan HUT Republik Indonesia, sangat antusias dengan berbagai kegiatan, kemudian kegiatan terhenti kembali. Beliau juga menambahkan salah satunya karena belum ada kegiatan yang mengikat anggota Karang Taruna maksudnya hanya musiman. Karena itu kegiatan pemberdayaan Karang Taruna dalam bentuk penyuluhan dan pelatihan sangat tepat apalagi kalau dibantu alatnya sehingga selesai pelatihan dapat diterapkan dan ketrampilannya semakin meningkat.

Tim selanjutnya melakukan silaturrahmi dengan Kepala Desa Cagakagung dengan Bapak Sapa'at bertempat di Kantor Desa Cagakagung pada tanggal 23 Mei 2015. Pada kesempatan ini tim yang dipimpin oleh Suprayoga, SE., M.Si., menyampaikan maksud kedatangan untuk melaporkan bahwa kegiatan pemberdayaan Karang Taruna di Desa Cagakagung akan dimulai, serta menyampaikan program kegiatan yang akan dilaksanakan, tidak lupa tim juga memohon arahan/masukan dari kepada desa dan memohon do'a restu agar pelaksanaan pemberdayaan Karang Taruna dapat berhasil sesuai dengan tujuan. Pada kesempatan ini bapak kepala desa menyampaikan ini seperti gayung bersambut karena 2 tahun terakhir ini, Karang Taruna selalu dilibatkan dalam kegiatan-kegiatan di desa baik menyangkut kepemudaan maupun pembangunan yang lain dan diberi kepercayaan untuk mengelola pembayaran listrik, distribusi air minum, dan kegiatan lainnya. Saya sangat berterima kasih kalau mendapat kesempatan pembinaan dari tim Universitas Wijaya Putra. Kebetulan malam nanti ada rapat Karang Taruna saya akan hadir dan sampaikan program tim ini, serta saya akan motivasi supaya dimanfaatkan dengan sebaik-baiknya.

Selain itu Bapak Kepala Desa juga menyampaikan pada dasarnya Karang Taruna Desa Cagakagung ini cukup aktif setiap bulan 
pasti ada rapat di kantor desa ini, memang saya fasilitasi, bapak kepala desa juga menyampaikan agar mental wirausahanya bisa ditumbuhkan supaya Karang Taruna menjadi lebih berdaya guna minimal bagi dirinya dan organisasinya, khususnya kepeimipinan dan kemampuan mengelola oraganisasi. Desa juga baru saja dapat bibit tanaman Mangga dan Sawo dari Petrokimia pengelolaannya juga saya serahkan Karang Taruna termasuk supaya dipikirkan jika kelak sudah pada berbuah. Pada kesempatan itu pula bapak kepala desa menyampaikan barangkali ada dosen atau tim lain bisa memberikan pembinaan di desa ini silahkan, karena disini juga banyak pembuat kue basah, kerajinan sarung, kalau didesa saya ingin data monografi desa ini menjadi baik dan akurat.

Aktifitas berikutnya tim mengadakan koordinasi internal pada tanggal 24 April 2015 untuk mengakomodir masukan dari Kepala Desa Cerme Lor, Kepala Desa Cagakagung dan pengurus Karang Taruna dari kedua desa tersebut. Selanjutnya tim menetapkan materi kegiatan penyuluhan dan pelatihan serta menyusun jadwal kegiatan mulai dari penyuluhan, pelatihan sampai dengan monitoring selanjutnya di komunikasikan ke mitra IbM. Adapun kegitan tersebut meliputi :

\section{Pelaksanaan}

Pelaksanaan kegiatan diawali dengan pembukaan kegiatan pemberdayaan Karang Taruna Desa Cerme Lor dan Karang Taruna Desa Cagakagung yang dilaksanakan pada tanggal 26 April 2015 di gedung pertemuan Universitas Wijaya Putra yang dihadiri oleh : pengurus Karang Taruna dan anggota Karang Taruna yang akan mengikuti kegiatan pelatihan Las Listrik, Service AC, dan pelatihan aneka olahan Jamur Tiram. Kegiatan tersebut selain dihadiri oleh pengurus dan anggota Karang Taruna juga dihadiri 4 orang mahasiswa jurusan teknik mesin dan jurusan akuntansi yang juga turut membantu kegiatan IbM Pemberdayaan Karang Taruna ini

Acara pembukaan kegiatan IbM Pemberdayaan Karang Taruna ini secara formalitas diawali dengan menyanyikan lagu kebangsaan Indonesia Raya yang dipimpin oleh Ika Yulia Sari (mahasiswa Fakultas Ekonomi jurusan Akuntansi), acara dilanjutkan dengan laporan ketua tim pelaksana IbM Karang Taruna Bapak Suprayoga, SE., M.Si. pada kesempatan ini ketua tim menyampaikan ucapan terima kasih kepada Bapak Kepala Desa Cerme Lor dan Bapak Kepala Desa Cagakagung yang telah berkenan dan merestui pengurus Karang Taruna sebagai mitra dalam kegiatan ini. Pada kesempatan itu juga disampaikan arti penting pemberdayaan Karang Taruna khususnya menghadapi persaingan bebas dikawasan ASEAN (MEA)

Pada kesempatan yang sama kaur bidang Kesra Bapak Niti Susastro yang mewakili Kepala Desa menyampaikan ucapan terima kasih karena telah memberikan kesempatan kepada Karang Taruna untuk di didik mengikuti pelatihan pemberdayaan Karang Taruna, yang terus terang saja pembinaan Karang Taruna di desa kami belum tergarap secara optimal karena keterbatasan kemampuan dan tenaga yang dimiliki oleh desa. Saya berharap pembinaan seperti ini bisa dilakukan secara berkala dengan pembekalan yang berbeda sehingga akan sangat banyak membantu jalanya pembangunan di desa kami, khususnya pembangunan sumberdaya manusia. Pada kesempatan itu juga Bapak Niti Susastro menyampaikan kepada peserta pelatihan agar dapat memanfaatkan kesempatan ini dengan sebaik-baiknya mengingat tidak semua mendapat kesempatan seperti saudara.

Akhirnya tepat pada 26 April 2015 pukul 10.00 WIB acara dibuka secara langsung oleh Wakil Rektor Bidang Akademik dan Kemahasiswaan di gedung pertemuan Universitas Wijaya Putra. Pada kesempatan itu bapak Wakil Rektor menyampaikan bahwa Perguruan tinggi khususnya Universitas Wijaya Putra bukanlah sebuah menara gading yang menjadikan hubungan masyarakat termasuk pemuda dalam hal ini Karang Taruna dengan kampus menjadi jauh. Sepanjang di kampus ini ada dan tersedia bisa dimanfaatkan untuk turut serta memberdayakan pemuda khususnya Karang Taruna. Pada kesempatan itu bapak Wakil Rektor juga menyampaikan apresiasi kepada tim pelaksana IbM Pemberdayaan Karang Taruna, karena ditangan pemudalah masa depan bangsa ini bisa banyak diharapkan. Oleh sebab itu 
pembinaan yang melibatkan generasi muda baik Karang Taruna maupun organisasi pemuda yang lain sangat tepat dan bijaksana. Semoga dari tahun ke tahun semakin banyak dosen yang melaksanakan pengabdian kepada masyarakat bisa menjadikan wujud nyata sumbangsih Universitas Wijaya Putra kepada masyarakat.

Acara dilanjutkan dengan pengarahan tim IbM pemberdayaan Karang Taruna mengenai tata tertib selama mengikuti rangkaian acara baik ketika penyuluhan (ceramah dan Tanya jawab) maupun ketika praktek di bengkel Fakultas Teknik Universitas Wijaya Putra untuk mentaati prosedur yang telah ditetapkan agar keselamatan kerja selama pelatihan dapat terjamin.

\section{Penyuluhan dan Pelatihan.}

Kegiatan penyuluhan dan pelatihan dalam kegiatan pemberdayaan Karang Taruna ini dilaksanakan selama 3 bulan mulai dari bulan April sampai dengan Juni. Sesuai dengan kesepakatan bersama kegiatan ini dilaksanakan seminggu satu kali pada hari minggu. Kegiatan penyuluhan dilakukan dengan model ceramah dan tanya jawab dengan mendatangkan nara sumber sesuai dengan keahlian masing-masing.

Setelah acara pembukaan, dilanjutkan dengan materi "Dinamika Kelompok" yang disampaikan oleh Bapak tim Andi Iswoyo, SE., MM. Materi ini dimaksudkan untuk mencairkan suasana agar peserta pemberdayaan Karang Taruna yang berasal dari dua desa yang berbeda ini bisa saling mengenal, dan keberadaan peserta dengan melaksanakan kegiatan di kampus yang cenderung kaku bisa lebuh dalam suasana yang menyenangkan. Acara dimulai dengan kegiatan Ice Breaaking untuk menyeimbangkan penggunaan otak kanan dan otak kiri. Dengan cara jari diperagakan sebagai kelinci dan sebagai alat tembak dilakukan secara bergantian, kelinci diperagakan tangan kanan dan alat tembak tangan kiri demikian sebaliknya dan dilakukan berulang kali dilanjutkan kegiatan sejenis dengan beda gerakan. Selanjutnya dilakukan kegiatan melempar bola, peserta membentuk lingkaran besar, selanjunya peserta diberikan permasalahan dengan ketentuan : 1) sebelum melempar bola harus menyebut nama orang yang akan diberi bola baru menyebutkan namanya sendiri, 2) bola dilempar minimal melewati 5 orang, 3) setiap peserta hanya boleh menerima dan melempar satu kali, 4) bola tidak boleh jatuh selama kegiatan berlangsung. Dengan demikian suasana yang semula cenderung beku menjadi cair dan karena terjadi pengulangan beberapa kali karena tidak sesuai dengan aturan main, maka tanpa disadari diantara peserta saling mengenal satu sama lain dalam suasana penuh keceriaan. Kondisi demikian ini sangat penting untuk kelanjutan kegiatan berikutnya karena suasana sudah cair dan tidak lagi selalu berkelompok sesuai dengan asal desanya. Mereka sudah berkumpul secara kelompok sesuai yang diminta nara sumber yaitu berkelompok menjadi 5 orang perkelompok. Masing-masing kelompok diminta untuk mendiskusikan dan menyampaikan permasalahan yang ada dalam pengelolaan Karang Taruna di tingkat desa.

Materi kedua pada hari yang sama adalah "Peranan Generasi Muda Dalam Pembangunan Bangsa" yang disampaikan oleh Bapak Dr. Taufiqurrahman, SH., M.Hum. Mantan Wakil Ketua DPD KNPI Tingkat I Jawa Timur ini membuka cakrawala pemikiran peserta tentang arti penting pemuda / Karang Taruna dalam pembangunan bangsa. Apa esensi dari peran Karang Taruna dalam pembangunan dan bagaimana penerapannya dalam kehidupan berorganisasi. Bagaimana Karang Taruna lebih bisa berdaya minimal untuk dirinya ditengah sengitnya persaingan mendapatkan kesempatan kerja lebih-lebih di era persaingan bebas ini, selain itu bagaimana Karang Taruna bisa berdaya untuk lingkungannya, minimal dilingkup organisasi kepemudaan agar ditak mudah di adu domba dan dipecah belah apalagi terpengaruh dengan cara-cara instan untuk cepat sukses dengan terlibat obat-obatan terlarang.

Berikutnya pada tanggal 3 Mei 2015 peserta pemberdayaan Karang Taruna mendapat pencerahan berupa materi "Success Story" dan "Kewirausahaan". Peserta akan mendapatkan pengalaman yang berharga dari 
pengusaha muda yang sukses merambah bisnis dari kecil, yaitu Tririan Arianto. Dengan keuletan, kegigihan berusaha dan keterbukaan untuk menerima hal-hal baru, matan lulusan STT Bandung itu memberanikan diri masuk dalam belantara Wirausaha bidang yang ditekuni adalah pengolahan Jamur Tiram, selain tetap bergerak di bidang Teknik Informatika. Berkat ketekunan dan keuletannya tersebut, saat ini Bapak Rian memiliki gerai di Surabaya, Gresik, dan Sidoarjo

Acara selanjunya pada hari Minggu, tanggal 10 Mei 2015 dengan materi "Internet Positif dan Pemanfaatannya" yang disampaikan oleh Bapak Suryo Atmodjo, ST., MT. Ketua Program Studi Teknik Informatika Universitas Wijaya Putra. Pada kesempatan ini, Bapak Suryo memberikan kesempatan kepada peserta untuk mengisi survey tentang pengalamannya menggunakan computer dan smartphone dan bagaimana mereka memanfaatkannya yang disajikan dalam survey online. Berikutnya beliau memberikan ulasan tentang manfaat positif internet, diantaranya untuk mencari informasi, lebih efisien, memudahkan komunikasi, meningkatkan penguasaan bahasa asing, mendorong kemandirian, sarana pendidikan jarak jauh, sebagai sarana hiburan, memudahkan pekerjaan, untuk menjalankan bisnis dan bisa untuk berbelanja, berikutnya peserta diajak untuk membuat email baru, membuat blog, membuat folder dokumen melalui fasilitas cloud document, menyimpan pada cloud storage dan belajar pemrograman web. Semua materi tersebut disampaikan secara online yang sudah disiapkan oleh Bapak Suryo melalui blog pribadinya uyok.blogid.me

Pelaksanaan Las \& AC pada tanggal 17, 24, 31 Mei 2015 dan tanggal 2, 7, dan 14 Juni 2015. Kegiatan pelatihan Las Listrik diikuti oleh 13 Peserta dari kedua desa mitra yang diajarkan oleh Bapak Hendra Mujiono, ST. dari Pusat Penelitian dan Pengembangan Teknologi Terapan - Universitas Wijaya Putra. Adapun materi yang diberikan berupa teori dan praktek meliputi :

1) Pengenalan Material dan Peralatan

2) Keamanan dan Keselamatan Kerja (K3)

3) Proses penyalaan Las

4) Proses pembuatan alur pengelasan
5) Membuat sambungan pengelasan rata

6) Membuat sambungan pengelasan bertingkat

7) Pembuatan media

Kegiatan pelatihan Service AC diikuti oleh 10 Peserta dari kedua desa mitra yang diajarkan oleh Jupri, ST., MM. Guru SMK Negeri 1 Cerme Gresik Adapun materi yang diberikan berupa teori dan praktek meliputi :

1) Pengenalan komponen dan peralatan $\mathrm{AC}$

2) Prosedur melakukan perawatan ringan / service AC

3) Proses pengisian Freon $\mathrm{AC}$

4) Proses pembuatan sambungan pemipaan $\mathrm{AC}$

5) Instalasi $\mathrm{AC}$

6) Praktek lapangan melakukan service / perawatan AC

Pada tanggal 24 Mei 2015 dilaksanakan pelatihan Budidaya Jamur. Pelatihan Budi daya jamur tiram ini dilaksanakan secara langsung ditempat budidaya yaitu di Desa Gedangan, Kecamatan Gedangan Sidorajo. Yang disampaikan oleh Bapak Anton sebagai pemilik usaha budidaya jamur tiram. Peserta mendapat materi tentang bagaimana menyiapkan media tanam yaitu dari serbuk gergaji kayu jati dan mahoni, dipilih dan dibersikan, kemudian membuat log dalam bag plastic transparan kemudian diujungnya diberi cincin dan diikat, proses berikutnya adalah pengukusan log selama 8-12 jam, selanjutnya dilakukan penanaman bibit setelah log dingin. Materi dilanjutkan dengan proses penumbuhan jamur, dimulai dari menyiapkan tempat, pengaturan suhu, kelembaban dan cahaya. Kurang tepat dalam pengaturan suhu, kelembaban dan cahaya dapat mempengaruhi produktivitas panen jamur. Panen jamur bisa dilakukan 3-5 hari setelah bibit tumbuh jadi tunas jamur. Dari 1 $\log$ dapat dihasilkan $0,8-1 \mathrm{~kg}$ jamur yang dijual secara curah perkilo seharga Rp. $10.000,-$, jika dijual perkilo dan dipacking secara bagus bisa terjual seharga Rp. 23.000,-/ kilo.

Tanggal 31 Mei 2015 Pengolahan jamur. Pelatihan pengolahan jamur tiram menjadi berbagai macam olahan makanan disampaikan oleh Bapak Tririan Arianto, ST. seorang wirausahawan yang telah memiliki gerai olahan makanan jamur di Surabaya, 
Gresik dan Sidoarjo. Pelaksanaan pelatihan dilaksanakan di rumah Bapak Tririan Arianto Perumahan Sidokare Indah Blok R-7 Sidoarjo. Pelatihan ini diikuti oleh 17 orang kebanyakan perempuan anggota Karang Taruna dari 2 desa mitra, serta ada ibu PKK sebanyak 3 orang yang karena sangat tertarik pada pelatihan ini untuk ikut serta. Pelatihan dilakukan dengan penuh semangat dan senang, diawali dari tim pelaksana menyampaikan kata pengantar dan menyerahkan peserta pelatihan kepada Bapak Tririan. Selanjutnya Bapak Tririan Arianto memulai dengan cara memperkenalkan aneka olahan jamur yang sudah dikemas dengan baik dan masih dingin karena baru diambil dari lemari pendingin.

Peserta tampak antusias walau baru ditunjukan produk olahan yang telah dipesan pelanggan nara sumber. Selanjutnya nara sumber menyampaikan bahwa pada kesempatan pelatihan ini peserta akan diajarkan beberapa makanan olahan dari jamur, tidak bisa semua dipraktekkan mengingat keterbatasan waktu yang ada, nara sumber menyampaikan yang akan dipraktekan kali ini 1) membuat jamur krispi; 2) membuat kebab jamur; 3) membuat sate jamur; 4) membuat empal jamur untuk disajikan dalam bentuk jamur penyet.

Pertama yang diajarkan pembuatan jamur krispi, salah satu kelebihan makanan olahan produk nara sumber ini terletak pada tepung yang dipakai menggoreng jamur sehingga bisa renyah dan gurih. Tepung yang dimaksud adalah produk dari Bapak Tri rian selanjutnya dicampur dengan tepung biasa yang tersediaditoko-toko. Dari sini sudah mulai nampak kejelian dalam berwirausaha, sebab orang yang akan mengembangkan sekalipun sudah terampil akhirnya tetap perlu beli master tepung dari Bapak Tririan agar cita rasanya tetap terjaga.

Peserta pelatihan diajarkan mulai cara memotong jamur, mencuci, membuat adonan dari tepung master dan tepung produk pabrik yang terjual di took-toko sampai dengan memasukkan ke adonan dan tepung sampai dengan penggorengan. Tidak hanya itu nara sumber juga membagi ilmunya dari cara penyajian sampai dengan pembuatan saos dan sambalnya. Ketika ditanya bagaimana cara menghitung harga pokok produksi, Bapak Tririan dengan senang hati menjelaskan tanpa ada yang ditutupi, tentunya selain resep tepung masternya. Setelah praktek pertama selesai maka hasil karya Karang Taruna selain dicoba dinikmati oleh nara sumber juga dinikmati oleh seluruh peserta pelatihan.

Praktek kedua bapak Tririan mengajarkan pembuatan Kebab Jamur. Diawali dengan menjelaskan bahan dasar kebab jamur, mulai kulit untuk kebab, sayur dan tomat juga olahan empal jamur hasil produk olahan pabrik yang telah diberikan rempah-rempah sehingga seperti empal dari jamur yang sudah dipotong kecil-kecil. Dengan telaten Bapak Tririan mengajarkan cara pembuatan kebab jamur sambil mengatakan sayur ini nilai kurang lebih sekian rupiah, empal jamur sebagai pengganti daging sekian rupiah, kulitnya, mayonaes, saos, sampai dengan harga bungkus kalau ada merek pesan dipercetakan maupun bungkus buatan sendiri dari plastic dicontohkan cara membuatnya. Selanjutnya dibakar dan diserahkan kepada tim untuk mencobanya. Selanjutnya setiap peserta diminta untuk mencoba membuat kebab untuk dirinya masing-masing sambil diawasi nara sumber dan asistennya. Harga pokok produksi kurang lebih Rp. 2.750,- sampai dengan Rp. 3.500,sedangkan rata-rata harga juah kalau di kota Rp 6.000,- s.d. Rp. 7.000,-. Kalau didaerah berkisar Rp. 5.000,- sampai dengan Rp. $6.000,-$.

Berikutnya peserta diajarkan membuat nasi jamur penyet. Pada kegiatan ini nara sumber menyampaikan bahwa farina dari empal jamur tadi bisa dipakai nasi jamur penyet, atau nasi jamur dalam kemasan yang menarik untuk anak-anak selain di buat kebab jamur. Kecerdikan nara sumber dalam berwirausaha semakin tampak ketika menjelaskan nasi jamur penyet, dimana salah satu keistimewaan diantara terletak pada sambelnya. Dalam pelatihan ini juga dijelaskan perhitungan harga pokok untuk nasi, empal jamur, sampai pada biaya pembuatan sambel dan harga jual 1 porsi nasi jamur penyet. Pada proses pembuatan sambal nara sumber menyampaikan bahwa pembuatan samber ini merupakan campuran dari tomat, 
cabe, sedikit gula dan garam serta master sambel produk Bapak Tririan. Kelebihan membuat master atau babon sambel inilah yang menjadikan orang yang diajari semua resep olahan jamur masih juga memerlukan bapak Tririan khususnya untuk suplai bahan master tersebut.

Pada tanggal 19 Juni 2015 Pelatihan Kepemimpinan dan keorganisasian, buka puasa bersama, penyerahan alat. Kegiatan selanjutnya dilaksanakan pada hari Jum'at tanggal 19 Juni 2015 bertempat dikantor desa Cagakagung, Cerme Gresik. Kegiatan diikuti oleh 42 anggota dan pengurus karang taruna peserta pelatihan pemberdayaan Karang Taruna dari kedua desa mitra dimulai pukul 15.15 WIB. Pada kesempatan itu Ketua Tim yang juga fasilitator outbond manajemen trining menyampaikan materi kepemimpinan dan keorganisasian. Walaupun kondisi bulan puasa acara berlangsung sangat menarik dan penuh keceriaan, karena penyajian materi kepemimpinan yang disajikan bukan hanya bentuk ceramah dan Tanya jawab tetapi diaplikasikan dalam bentuk permainan setelah itu didiskusikan bersama kelompok. Dengan demikian pemahaman akan materi kepemimpinan, bagaimana memimpin dan tantangan bagi seorang pemimpin dapat tercermin secara langsung melalui permaian yang diberikan. Demikian juga dengan materi keorganisasian tidak kalah menariknya ketika dilaksanakan dalam bentuk permaian di balai desa Cagakagung. Tanpa terasa 100 menit dilalui dengan kegembiraan dan penuh canda tawa sampai lupa kalau sedang berpuasa.

Sebelum acara diakhiri dilanjutkan dengan penyerahan seperangkat alat Las Listrik dan seperangat alat service AC masingmasing kepada pengurus Karang Taruna melalui kepala desa. Ketua timberpesan hendaknya setelah alat ini diserahkan bisa dipergunakan seoptimal mungkin akan Karang Taruna semakin berdaya, dan tim menjanjikan akan mendapingi dalam kurun waktu sampai akhir bulan Agustus 2015. Pada kesempatan yang sama bapak kepala desa Cagakagung dalam sambutannya menyampaikan ucapan terima kasih pada tim dari Universitas Wijaya Putra, serta berharap adanya bantuan ketrampilan dan alat Las dan Service AC semakin menambah Karang Taruna berdaya guna baik untuk dirinya maupun lingkungannya. Selanjutnya acara berdoa bersama yang dipimpin saudara Prabowo Jazuli pengurus Karang Taruna Cagakagung dilanjutkan dengan buka puasa bersama sambil menikmati olahan jamur hasil praktek peserta pelatihan aneka olahan jamur tiram

\section{Program Pendampingan}

Pada program ini, beberapa anggota Mitra ditempatkan pada beberapa pengusaha yang sesuai, diataranya pada usaha Las dan Mesin Perkakas milik Bapak Mulyono Desa Cagak Agung, usaha Ketok Magic dan Service Mobil milik Bapak Darto di Desa Cagak Agung, usaha Reparasi AC milik Bapak Ardianto Desa Cagak Agung, kelompok usaha Reparasi AC milik Bapak Jupri, Desa Cagak Agung dan usaha pembuatan Pagar dan Kanopi milik Bapak Bambang Desa Cerme Lor. Program pendampingan/magang ini dilakukan selama 2 minggu. Beberapa evaluasi dari program magang ini diantaranya; masih kurangnya kemampuan peserta dalam mengukur, kurang teliti, kurang berani mengambil resiko dan takut salah. Pengalaman yang didapat oleh peserta dari program ini sangat membantu kemauan berwirausaha sendiri dengan membentuk kelompok usaha. Berikut tabel distribusi peserta magang IbM Pemberdayaan Karang Taruna ini:

Tabel 5.1 Distribusi Peserta Magang

\begin{tabular}{|c|c|c|c|}
\hline No & Tempat & Alamat & $\begin{array}{l}\text { Jumlah } \\
\text { Peserta }\end{array}$ \\
\hline 1 & $\begin{array}{l}\text { Usaha Las dan Mesin Perkakas - } \\
\text { Bapak Mulyono }\end{array}$ & Desa Cagak Agung & 4 orang \\
\hline 2 & $\begin{array}{l}\text { Usaha Ketok Magic dan Service } \\
\text { Mobil - Bapak Darto }\end{array}$ & Desa Cagak Agung & 2 orang \\
\hline 3 & Usaha Reparasi AC - Bapak Ardianto & Desa Cagak Agung & 3 orang \\
\hline 4 & Usaha Reparasi AC & Desa Cagak Agung & 3 orang \\
\hline
\end{tabular}




\begin{tabular}{lllc}
\hline Bapak Jupri, & & \\
\hline 5 & $\begin{array}{l}\text { Usaha pembuatan Pagar dan Kanopi - } \\
\text { Bapak Bambang }\end{array}$ & Desa Cerme Lor & \\
\hline
\end{tabular}

Selain program magang seperti diatas, Tim Pelaksana juga melakukan pendampingan pada kegiatan keorganisasian karang taruna, diantaranya pendampingan saat pelaksanaan Peringatan Hari Besar Nasional HUT Kemerdekaan RI ke-70, diantaranya membantu mempersiapkan pelaksanaan lomba-lomba, jalan sehat dan bazaar yang dilakukan oleh Karang Taruna putri dengan menjual beberapa aneka makanan olahan dari jamur tiram. Pendampingan yang lainnya seperti pembinaan dalam pengelolaan keuangan dan sumber pendapatan karang taruna di Desa Cagak Agung melalui pengelolaan pembayaran Listrik, Air dan Kebersihan.

\section{Pembentukan Kelompok Usaha}

Setelah program pendampingan selesai, Tim Pelaksana IbM dan Mitra bersepakat untuk membentuk Kelompok Usaha bersama antar Karang Taruna, yaitu Kelompok Usaha Las dan Mesin Perkakas yang digagas oleh Karang Taruna Desa Cerme Lor yang kemudian difasilitasi oleh Kepala Desa Cerme Lor dengan menyediakan lahan di Balai RW untuk usaha tersebut. Saat ini sudah 6 orang anggota Karang Taruna yang terlibat dalam kelompok ini. Sebagian hasil usaha ini disetorkan ke kas Karang Taruna sebagai dana pengembangan dan kegiatan mereka.

\section{DAMPAK PEMBERDAYAAN KARANG TARUNA}

Setelah pelaksanaan kegiatan IbM Pemberdayaan Karang Taruna ini, dapat dilihat dampak sebagai berikut :

1. Kedua Mitra sudah membentuk Kelompok Usaha Mesin Perkakas dan Kanopi yang bertempat di Desa Cerme Lor Kab. Gresik

2. Peserta pelatihan AC sebagian sudah direkrut oleh Pengusaha reparasi AC dan Pendingin Udara

3. Beberapa anggota Karang Taruna putri sudah memulai usaha membuat dan menjual aneka makanan olahan Jamur Tiram
4. Aktivitas keorganisasian di kedua Mitra semakin meningkat ditandai dengan beberapa kegiatan yang oleh Kepala Desa pelaksanaannya diserahkan kepada Karang Taruna (Pembayaran Listrik, Air, PHBN, dll)

\section{DAFTAR PUSTAKA}

BPS Kabupaten Gresik, 2013, Gresik dalam Angka 2013, http://gresikkab.bps.go.id/, diakses tanggal 2 April 2014

BPS Kabuten Gresik, Stattistik Kecamatan Cerme 2013, diakses tanggal 2 April 2014

Pemerintah Kabupaten Gresik, Kecamatan Cerme dalam Angka 2013, http://gresikkab.go.id/data/KDA/05.\%20Kec. \%20Cermee.pdf, diakses tanggal 2 April 2014

Peraturan Menteri Sosial RI No. 77/HUK/2010 tentang Pedoman Dasar Karang Taruna

Puluhulawa, Mukhtar Junus, 2012, Peran Karang Taruna dalam Menciptakan Pemuda Produktif Di Desa Barakati Kecamatan Batudaa Kabupaten Gorontalo, Universitas Negeri Gorontalo. 